\title{
MONOPOLI DALAM PERSPEKTIF EKONOMI ISLAM
}

\author{
Dede Abdul Fatah*
}

\begin{abstract}
Monopoly in Islamic Economic Perspective. Monopoly in Islamic economic perspective means withholding or hoarding goods on purpose, especially in times of scarcity, with the goal of raising the price at a later date in order to obtain greater profits. Monopolistic practices is a type of violation will result in $m u$ 'âmalah because market mechanisms disrupted, so that producers will get a big profit (monopolistic rent), while the consumer due to the accumulation of actions will suffer and get loss. Therefore, this monopoly will bring people in general harmed by the act of a small group of monopolists very unjust, selfish and irresponsible.
\end{abstract}

Keyword: monopoly, scarcity, market mechanism

\begin{abstract}
Abstrak: Monopoli dalam Perspektif Ekonomi Islam. Monopoli dalam perspektif ekonomi Islam adalah menahan atau menimbun barang dengan sengaja, terutama pada saat terjadi kelangkaan, dengan tujuan menaikkan harga di kemudian hari agar mendapatkan keuntungan yang lebih besar. Praktik monopoli merupakan jenis pelanggaran dalam bermuamalah sebab akan mengakibatkan mekanisme pasar terganggu, sehingga produsen akan mendapatkan untung besar, sedangkan konsumen akibat tindakan penimbunan tersebut akan mengalami penderitaan dan kerugian. Jadi, akibat monopili, masyarakat luas akan dirugikan akibat ulah sekelompok kecil pelaku monopoli yang sangat zalim, egois, dan tidak bertanggung jawab.
\end{abstract}

Kata Kunci: monopoli, kelangkaan, mekanisme pasar

Naskah diterima: 5 September 2011, direvisi: 6 Januari 2012, disetujui: 12 januari 2012.

*Universitas Al-Azhar Indonesia (UAI). Jl. Sisingamangaraja, Jakarta Selatan. E-mail: dedefatah@yahoo.com 


\section{Pendahuluan}

Pasar merupakan sarana pertemuan penawaran dan permintaan antara penjual dan pembeli. Islam menghendaki kesempurnaan pasar yang bebas dari upaya pihak-pihak yang menghendaki distorsi pasar demi meraup keuntungan tinggi dalam waktu singkat. Oleh karena itu, ketidaksempurnaan pasar merupakan musuh bersama yang harus diantisipasi terutama oleh pihak yang memiliki otoritas, yaitu pemerintah bahkan negara. Ketidaksempurnaan pasar dapat disebabkan oleh upaya rekayasa pada sisi permintaan dan penawaran.

Rekayasa dari segi permintaan bisa berupa bay' najasy, yaitu penciptaan permintaan semu untuk menaikkan harga, sedangkan rekayasa dari segi penawaran bisa berupa ihtikâr (monopoli), yaitu upaya menghambat pasokan barang agar harga sesungguhnya menjadi tinggi, bisa juga berupa talaqqî al-rukbân, yaitu menghalangi transaksi pada harga sesungguhnya, dan bay al-hâahir li al-bâdî, yaitu praktik makelar (samsarah) yang dilakukan oleh seseorang (orang kota) terhadap orang yang datang dari perkampungan (gurun Sahara) untuk menjadi perantara dalam menjual barang dengan mengambil keuntungan yang sangat besar.

Ketidaksempurnaan pasar juga bisa muncul disebabkan ketidaksempurnaan informasi yang dimiliki oleh para pelaku ekonomi. Informasi merupakan hal yang penting, sebab ia menjadi dasar bagi pembuatan keputusan. Produsen berkepentingan untuk mengetahui seberapa besar permintaan dan tingkat harganya, berapa harga input dan teknologi yang tersedia, dan lain-lain, sehingga dapat menawarkan barangnya secara akurat. Demikian pula konsumen, ia harus mengetahui tingkat harga yang berlaku, kualitas barang yang dibelinya, dan lainlain, sehingga dapat menentukan permintaannya dengan akurat pula. Dari sekian banyak penyebab ketidaksempurnaan pasar, tampaknya ihtikâr (monopoli) merupakan faktor yang paling sering dilakukan oleh pihak-pihak yang tidak bertanggung jawab. Dengan demikian, kajian ini akan menfokuskan pembahasannya pada masalah monopoli (ihtikâr) dalam perspektif ekonomi Islam.

\section{Interpretasi Monopoli}

Monopoli dalam perspektif ekonomi Islam memiliki pengertian yang berbeda dengan monopoli dalam perspektif ekonomi konvensional. Dalam perspektif ekonomi Islam secara etimologi monopoli (ihtikâr) berasal dari kata alhukr yang artinya al-zhulm wa al-'isâ'ah al-mu'âsyarah, yaitu berbuat aniaya dan sewenang-wenang. ${ }^{1}$ Sedangkan secara terminologis, monopoli(ihtikâr) ${ }^{2}$ adalah

${ }^{1}$ Majd al-Dîn Muhammad ibn Ya‘qûb al-Fayrûz Abâdî al-Syîrâzî, al-Qâmûs al-Muhîth Juz II, (Bayrût: Dâr al-Fikr, 1398 H), h. 12. 
menahan atau menimbun (hoarding) barang dengan sengaja, terutama pada saat terjadi kelangkaan barang dengan tujuan untuk menaikkan harga di kemudian hari. Praktik ihtikâr akan menyebabkan mekanisme pasar terganggu, di mana produsen kemudian akan menjual dengan harga yang lebih tinggi dari harga normal. Penjual akan mendapatkan untung besar (monopolistic rent), sedangkan konsumen akan menderita kerugian. Jadi, akibat ihtikâr, masyarakat luas akan dirugikan akibat ulah sekelompok kecil yang tidak bertanggung jawab.

Sedangkan monopoli (dari bahasa Yunani: monos yang berarti satu dan polein yang berarti menjual) dalam perspektif ekonomi konvensional adalah suatu keadaan di mana di pasar hanya ada seorang penjual suatu barang, sehingga tidak ada pihak lain yang menyainginya. ${ }^{3}$ Ketentuan di atas termasuk ketentuan monopoli murni atau pure monopoly. Dalam kenyataan sulit untuk mendapatkan perusahaan yang tergolong monopoli murni. Di mana tidak ada unsur persaingan dari perusahaan lain. Karena seandainya hanya ada satu penjual di pasar, tetap masih ada kemungkinan perusahaan tidak langsung, misalnya produk-produk dari perusahaan lain yang bisa dijadikan sebagai substitusi (meski bukan substitusi sempurna) bagi produk-produk yang dihasilkan oleh perusahaan monopoli. Misalnya, PLN mendapat persaingan dari perusahaan yang menjual genset.

Monopoli mengharuskan adanya suatu cara untuk menyingkirkan para pe-

\footnotetext{
${ }^{2}$ Menurut Mâlikiyyah ihtikâr adalah menimbun barang dengan tujuan mencari keuntungan ketika pasar dalam keadaan tidak stabil. Lihat, al-Bâjî, Al-Muntaqâ Syarh al-Muwaththa' Juz V, (Bayrût: Dâr al-Kitâb al-'Arabî, 1332 H), h. 15. Menurut al-Kâsânî, ihtikâr adalah menimbun makanan pokok ketika masyarakat sangat membutuhkannya. Lihat, 'Alâ' al-Dîn Abû Bakr ibn Mas'ûd al-Kâsânî, Badâ'i' al-Shanâ'i' fì Tartîb al-Syarâ'i' Juz VI, (Zakariyâ 'Alî Yûsuf, t.th.), h. 2973. Menurut al-Syâfi'iyyah, ihtikâr adalah menimbun barang yang sangat dibutuhkan masyarakat banyak dengan tujuan mengambil keuntungan yang berlipat ganda. Lihat al-Syarbînî al-Khatîb, Mughnî al-Muhtâj ilâ Ma'rifat Ma'ânî Alfâzh al-Manhâj Juz II, (Mathba'at Mushthafâ al-Bâbî al-Hanbalî, t.th), h. 38. Menurut Hanabilah, ihtikâr adalah membeli makanan pokok yang dibutuhkan masyarakat banyak dan menimbunnya dengan tujuan untuk mengambil keuntungan yang berlipat ganda. Lihat, Ibn Taymiyyah, Al- $\underline{H} i s b a h$ (Riyâdh: Al-Mu'assasah al-Su'ûdiyyah, t.th), h. 37-38. Lihat juga Manshûr ibn Yûsuf ibn Idrîs al-Buhûtî, Kasysyâf al-Qinâ' 'an Matn al-Iqnâ' Juz III, (Bayrût: 'Allam al-Kitâb, t.th), h. 187.

${ }^{3}$ Ada beberapa ciri khusus suatu pasar dikatakan pasar monopoli di antaranya: Pertama, terdiri atas satu perusahaan, sehingga barang atau jasa yang dihasilkannya tidak dapat diperoleh dari perusahaan lain. Kedua, tidak mempunyai barang pengganti yang mirip. Artinya barang atau jasa yang dihasilkan tidak dapat digantikan oleh barang atau jasa lain yang ada di pasar. Ketiga, tidak terdapat kemungkinan perusahaan lain untuk masuk ke dalam industri. Keempat, dapat mempengaruhi penentuan harga. Kelima, promosi berupa iklan tidak diperlukan. Keenam, hanya satu produsen yang menguasai penawaran. Ketujuh, tidak dipengaruhi dan tidak mempengaruhi harga serta output dari produk-produk lain yang dijual dalam perekonomian. Lihat, Karl E. Case and Ray C. Fair, Principles of Economics, terj. Benyamin Molan, Prinsip-Prinsip Ekonomi Mikro (Jakarta: PT Prenhallindo, 2002), h. 341-344.
} 
saing dari arena sebuah industri tertentu. Akan tetapi untuk merealisasikan usaha tersebut harus menghadapi rintangan (barriers) yang tidak sedikit di antaranya hak paten ${ }^{4}$ dan lisensi ${ }^{5}$ yang dilakukan oleh pemerintah, pengendalian bahan baku, penggunaan nama merk, kebijakan harga yang dirancang untuk menahan pesaing di luar industri, investasi modal besar yang diperlukan untuk memasuki industri, dan luasnya pasar.

Kepemilikan suatu sumber daya yang unik (istimewa) yang tidak dimiliki oleh orang atau perusahaan lain merupakan salah satu penyebab terjadinya pasar monopoli. ${ }^{6}$ Di samping sumber daya yang unik dan istimewa skala ekonomis merupakan faktor yang dipertimbangkan terbentuknya pasar monopoli. Pada waktu perusahaan mencapai keadaan di mana ongkos produksi mencapai batas minimum, jumlah produksi adalah hampir menyamai jumlah permintaan yang ada di pasar. Dengan demikian, sebagai akibat dari skala ekonomis, perusahaan dapat menurunkan harga barangnya apabila produksi semakin tinggi. Pada tingkat produksi yang sangat tinggi, harga secara otomatis akan semakin rendah, sehingga perusahaan-perusahaan baru tidak sanggup bersaing dengan perusahaan yang terlebih dahulu berkembang. Keadaan ini menyebabkan terbentuknya pasar monopoli. ${ }^{7}$ Pasar monopoli juga dapat

${ }^{4}$ Paten berfungsi merangsang penemuan dan pembaharuan. Produk baru dan proses baru dikembangkan melalui riset yang dikembangkan melalui riset yang dilakukan oleh penemu perorangan dan oleh perusahaan. Riset membutuhkan sumber daya, waktu, biaya, dan peluang. Tanpa perlindungan yang berikan oleh paten, hasil riset akan menjadi cepat tersedia bagi masyarakat umum. Apabila riset tidak menjurus pada berkembangnya laba, maka sedikit sekali riset yang akan dilakukan. Namun pada sisi negatifnya, paten memang menghalangi munculnya persaingan dan memperlambat mengalirnya manfaat riset yang mengalir dari pasar menuju konsumen. Lihat Karl E. Case and Ray C. Fair, Principles of Economics, h. 344.

${ }^{5}$ Habisnya masa paten (20 tahun yang berlaku di Amerika) setelah beberapa tahun tertentu merupakan usaha untuk menyeimbangkan manfaat bagi perusahaan dan manfaat bagi masyarakat. Di samping pembatasan masa paten alternatif lain yang dilakukan agar suatu riset dapat dinikmati oleh masyarakat adalah memberi lisensi. Dengan memberi lisensi, teknologi baru bisa digunakan oleh semua produsen, dan sipenemu berbagi manfaat dengan para konsumen. Karena memaksa produsen yang tidak memegang paten untuk menggunakan teknologi yang tidak efisien akan menimbulkan pemborosan, sejumlah analis telah mengusulkan menambahkan pemberian lisensi yang bersifat wajib pada sistem paten yang berlaku sekarang. Lihat, Karl E. Case, Principles of Economics, h. 344.

${ }^{6}$ Contohnya suara emas yang dimiliki oleh seorang penyanyi terkenal atau kemampuan bermain yang sangat luar biasa dari seorang pemain sepak bola. Hanya merekalah yang mempunyai kepandaian tersebut dan harus dibayar lebih mahal dari biasanya apabila masyarakat ingin menikmatinya. Lihat, Sadono Sukirno, Pengantar Teori Mikroekonomi, h. 263.

${ }^{7}$ Suatu industri yang skala ekonomisnya mempunyai sifat seperti ini disebut monopoli alamiah (natural monopoly). Monopoli alamiah pada umumnya dijumpai dalam perusahaan jasa umum seperti perusahaan listrik, perusahaan telepon, dan perusahaan angkutan kereta api. Di 
terbentuk melalui peraturan pemerintah yang mengatur kegiatan perusahaanperusahaan yang mewujudkan kekuasaan monopoli seperti peraturan paten dan hak cipta, hak usaha eksklusif yang diberikan kepada perusahaan jasa umum.

Berdasarkan pengertian di atas, maka terdapat titik persamaan dan perbedaan antara ekonomi Islam dan konvensional dalam mendefinisikan monopoli. Titik persamaannya adalah sama-sama menghendaki adanya keuntungan yang besar, sedangkan perbedaannya pada cara dan motif mendapatkan keuntungan besar tersebut. Monopoli dalam Islam dilakukan dengan cara menimbun barang, sedangkan ekonomi konvensional bukan hanya dengan menimbun saja, akan tetapi dengan banyak cara, seperti kepemilikan suatu sumber daya unik (istimewa) yang tidak dimiliki oleh orang atau perusahaan lain, skala ekonomis, dan lain sebagainya. Dengan demikian, apapun yang dilakukan pihak tertentu untuk mencari keuntungan dengan cara membuat kelangkaan suatu barang dapat disebut monopoli (ihtikâr) dalam perspektif ekonomi Islam. Definisi-definisi monopoli dalam perspektif konvensional yang tujuan dan motifnya menzalimi dan merugikan orang lain, maka dapat dikategorikan monopoli, begitu pula sebaliknya, apabila motifnya tidak untuk menzalimi pihak lain, maka tidak dikatakan monopoli.

\section{Hukum Monopoli}

Jumhur ulama berpendapat bahwa monopoli hukumnya haram sebagaimana dikemukakan oleh ulama kalangan Hanâbilah, Mâlikiyyah, Hanafiyyah, dan mayoritas Syâfi'iyyah. Argumentasi yang mereka bangun adalah dalil naqlî dan 'aqlî. Di antara dalil naqlî yang mereka jadikan landasan hukum adalah Alquran dan Sunah. Allah Swt. berfirman dalam surah al-Hajj [22] ayat 25:

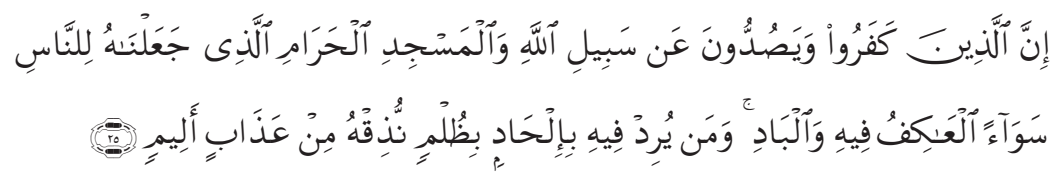

Sesungguhnya orang-orang yang kafir dan menghalangi manusia dari jalan Allah dan Masjidil Haram yang telah Kami jadikan untuk semua manusia, baik yang bermukim di situ maupun di padang pasir dan siapa yang bermaksud di dalamnya melakukan kejahatan secara zalim, niscaya akan

beberapa jenis industri lain skala ekonomis tidak mewujudkan monopoli, tetapi satu atau beberapa perusahaan memproduksi barang yang hampir sama jumlahnya dengan yang ditawarkan di pasar seperti perusahaan baja, pembuatan mobil dan pertambangan minyak. Lihat, N. Gregory Mankiw, Principles of Economics (New York: Harcourt College Publishers, 2001), h. 318-319. 
Kami rasakan kepadanya sebagian siksa yang pedih. (Q.s. al-Hajj [22]: 25)

Ibn Katsîr dalam karya fenomenalnya, Tafsîr Ibn Katsîr, menyatakan bahwa yang dimaksud dengan إحَاد dalam ayat tersebut adalah perilaku monopoli yang mana pelakunya diancam dengan siksaan yang sangat pedih. Hal ini menunjukkan bahwa monopoli yang dapat menimbulkan kelangkaan suatu barang yang sangat dibutuhkan masyarakat merupakan suatu kezaliman dan kejahatan. ${ }^{8}$ Hal ini diperkuat oleh hadis yang diriwayatkan oleh Abû Dâwûd dari Ya'lâ ibn Umayyah:

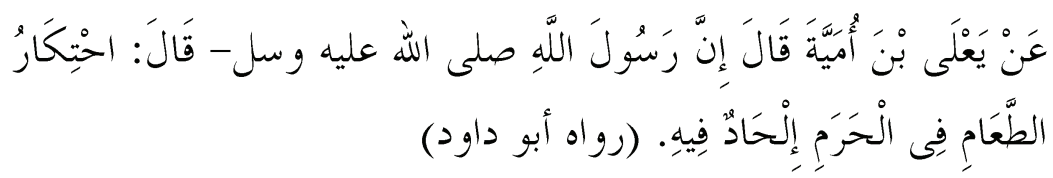

Dari Ya'lâ ibn Umayyah berkata, sesungguhnya Rasulullah Saw. bersabda, "Monopoli suatu makanan di sekitar masjid al-Haram adalah suatu kejahatan". (H.r. Abû Dâwud) ${ }^{9}$

Begitu pula Hadis yang diriwayatkan oleh Ibn Mâjah dari 'Umar ibn alKhaththâb:

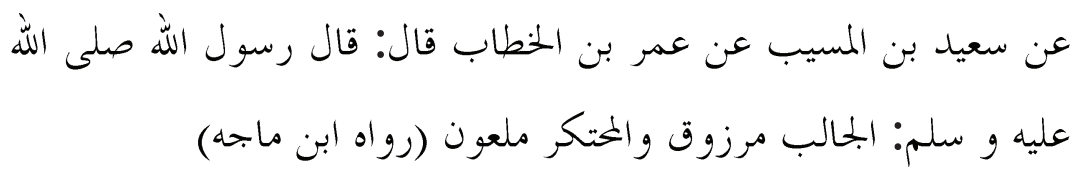

Dari Sa'îd ibn al-Musayyab dari 'Umar ibn al-Khaththâb berkata, Rasulullah Saw. bersabda, "Orang yang menawarkan barangnya untuk dijual akan memperoleh keberkahan rezeki, sedangkan orang yang melakukan monopoli, baginya laknat Allah Swt." (H.r. Ibn Mâjah) ${ }^{10}$

${ }^{8}$ Ibn Katsîr, Tafsir Ibn Katsîr Juz III, (Mishr: Dâr ihyâ al-Kutub al-'Arabiyyah, t.t), h. 215.

${ }^{9}$ Abû Dâwûd, Sunan Abî Dâwud Juz II,(Bayrût: Dâr al-Kitâb al-'arabî, tt), h. 161.

${ }^{10}$ Ibn Mâjah, Sunan Ibn Mâjah Juz II, (Bayrût: Dar al-Fikr, tt), h. 728. lihat juga hadis yang diriwayatkan oleh Imam Muslim dari Sa‘îd Ibn Musyyab:

$$
\text { من احتكر فهو خاطئ (رواه مسلم) }
$$

Barang siapa yang melakukan ihtikâr maka ia berdosa (H.r. Muslim). Lihat Imâm Muslim, Shahîh Muslim Juz V (Bayrût: Dâr al-Jayl, t.th), h. 56.

Begitu pula hadis Rasulullah Saw.: 
Sebagian ulama menyatakan bahwa yang dimaksud إحََادٍ dalam ayat tersebut adalah menyekutukan Allah Swt., menghalalkan yang haram, menghardik pembantu, dan sebagainya. Selain Alquran dan Hadis Rasulullah, keharaman monopoli ini diperkuat oleh âtsâr al-Shahâbah, di antaranya âtsâr 'Umar ibn al-Khththâb" ${ }^{11}$, 'Utsmân ibn 'Affân ${ }^{12}$, dan 'Alî ibn Abî Thâlib. ${ }^{13}$

Argumentasi yang dibangun oleh ulama yang mengharamkan monopoli (ihtikâr) tidak hanya bersumber dari dalil naql saja, akan tetapi bersumber pula dari dalil 'aql. Mereka mengemukakan bahwa monopoli sangat erat kaitannya dengan hajat orang banyak yang ketika salah satu pihak melakukannya akan menghambat pihak lain untuk memenuhi kebutuhannya, kalaupun dapat memenuhinya, mereka mendapatkannya dengan harga yang cukup tinggi. Hal tersebut merupakan kezaliman yang tidak bisa diteloransi. Ihtikâr hanya merea-lisasikan kemaslahatan individu, bukan kemaslahatan umum, apabila kemas-lahatan individu berbenturan dengan kemaslahatan umum, maka kemaslahatan umumlah yang didahulukan ${ }^{14}$

Namun tidak termasuk monopoli yang dilakukan pada situasi di mana

$$
\begin{aligned}
& \text { عن معقل بن يسار ، قال معقل بن يسار : سمعت رسول الله صلّى الله عليه وسلّم ، يقول: مندخل في شيء من أسعار المسلمين }
\end{aligned}
$$

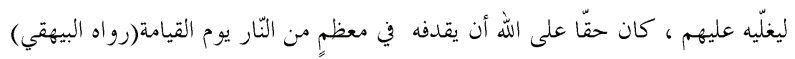

Dari Zayd ibn Abî Mu'allâ al-'Adawî saya mendengar al-Hasan berkata, 'Ubayd Allâh ibn Ziyâd bertemu dengan Ma'qal ibn Yasâr, Ma'qal ibn Yasâr berkata, Saya mendengar Rasulullah Saw. bersabda, "Barangsiapa yang menjual barangnya kepada kaum muslimin dengan harga yang sangat tinggi, maka Allah akan memasukkannya ke dalam api neraka." (H.r. Ahmad). Lihat Abû Bakr Ahmad ibn al-Husayn ibn 'Alî al-Bayhaqî, Al-Sunan al-Kubrâ Juz VI, (Haydar Âbâd: Majlis Dâ'irat al-Ma'ârif al-Nizhâmiyyah al-Kâ'inah fî al-Hind, 1344 H), h. 30.

11،Umar ibn al-Khaththâb berkata:

$$
\begin{aligned}
& \text { لا حكرة في سوقنا. لا يعمد رجال بأيديهم فضول من أذهاب، إلى رزق من رزق الله نزل بساحتنا، فيحتكرونه علينا، لكن } \\
& \text { أينما جالب جلب على عمود كبده في الشتاء والصيف، فذلك ضيف عمر فليبع كيف شاء الله، وليمسك كيف شاء. }
\end{aligned}
$$

Lihat al-Bâjî, al-Muntaqâ Juz V, h. 15.

12‘Utsmân ibn 'Affân berkata:

$$
\text { كان عثمان بن عفان ينهى عن الحكرة }
$$

Utsmân ibn 'Affân melarang perilaku monopoli. Lihat Al-Bâjî, al-Muntaqâ Juz V, h. 17.

13،Alî ibn Abî Thâlib berkata:

$$
\text { عن علي أنه مر بشط الفرات ، فإذا كدس طعام لرجل من التجار حبسه ليغلي به ، فأمر به فأحرق. }
$$

Dari 'Alî ibn Abî Thâlib beliau mengnjungi Syath al-Furath tiba-tiba beliau menemukakan beberapa pedagang menimbun dagangan (makanan) mereka dengan maksud meninggikan harganya, maka seketika itu Ali membakar dagangan mereka. Lihat 'Alî ibn Hisyâm al-Dîn, Kanz al-'Ummal IV, (Jam‘iyyat Dâ'irah al-Ma'ârif, 1395 H), h. 103.

${ }^{14}$ Sebagaimana yang dikemukakan oleh Hanafiyyah, Syâfi'iyyah, Hanâbilah, dan Mâlilikiyyah. Lihat al-Ikhtiyâr, Juz III, h. 115. Lihat juga al-MuhadzdzabJuz I, h. 318. Lihat juga al-Mughnî Juz IV, h. 283. Lihat juga al-Mudawwanah, Juz I, h. 123. 
pasokan barang melimpah, ${ }^{15}$ misalnya ketika terjadi panen besar, dan segera menjualnya ketika pasar membutuhkannya atau menimbun barang dengan tujuan untuk memenuhi kebutuhan keluarganya dan bukan untuk dijual dengan harga yang tinggi ketika masyarakat sangat membutuhkannya. ${ }^{16}$ Karena dalam situasi panen besar, apabila tidak ada pihak yang bersedia membeli/menampung hasil panen tersebut, maka harga yang terbentuk di pasar akan semakin melemah. Hal ini justru akan merugikan petani yang dalam hal ini merupakan pemasok terbesar.

Al-Bâjî (403-494 H) seorang ulama Mâlikiyyah dalam karyanya, al-Munta$q \hat{a},{ }^{17}$ mengategorikan ihtikâr sebagai perbuatan yang diharamkan dengan alasan bahwa ihtikâr merupakan kezaliman yang dapat merugikan orang lain. Pendapat al-Bâjî (403-494 H) diperkuat oleh Ibn Qudâmah (w 620 H) yang mengatakan bahwa ihtikâr dapat membahayakan jiwa orang banyak terlebih apabila yang ditimbun berupa makanan pokok.

Berbeda dengan al-Bâjî dan Ibn Qudâmah, al-Syîrâzî (w 476 H) ${ }^{18}$ dalam karyanya, al-Muhadzdzab, menyatakan bahwa hukum ihtikâr adalah makrûh tanzîh ${ }^{19}$, sedangkan menurut al-Subkî (w 750 H), hukum ihtikâr adalah makrûh tahrîm. ${ }^{20}$ Argumentasi yang mereka bangun adalah kekhususan larangan yang terkadung dalam atsar hanya berlaku untuk Hâkim ibn Hizâm tidak yang lainnya. Hal ini sesuai dengan kaidah العبرة بعوم اللفظ لا بخصوص السبب kecuali ada qarînah

15‘Alâ' al-Dîn Abî Bakr ibn Mas'ûd Al-Kâsânî, Badâ'i` al-Dhâ'i‘ fî̀ Tartîb al-Syarâ'i‘ Juz VI (Zakariyâ 'Alî Yûsuf, t.t), h. 2973. Lihat juga Al-Bâjî, Al-Muntaqâ Juz V,16. Lihat juga Muhammad AlSyarbînî al-Khatîb, Mughnî al-Muhtâj ilâ Ma'rifat Ma'ânî Alfâzh al-Minhâj Juz II (Qâhirah: Mushthafâ alBâbî al-Halibî wa Aulâdih, 1958), h. 38. Lihat juga Abu Muhammad 'Abd Allah ibn Ahmad ibn Muhammad ibn Qudâmah, Al-Mughnî Juz IV (Qâhirah: Maktab al-Qâhirah, 1968), h. 167. Lihat juga Manshûr ibn Yûsuf ibn Idrîs al-Buhûtî, Kasysyâf al-Qinâ' 'an Matan al-Iqnâ‘ Juz III, h. 187.

${ }^{16} \mathrm{Al}-\mathrm{Bâjî̀,} \mathrm{al-Muntaqâ} \mathrm{Syarh} \mathrm{al-Muwaththa'} \mathrm{Juz} \mathrm{V,} \mathrm{15.} \mathrm{Lihat} \mathrm{juga} \mathrm{al-Syarbînî,} \mathrm{Mughnî} \mathrm{al-Muhtâj}$ Juz II , 38. Lihat juga Al-Buhûtî, Kasysyâf al-Qinâ‘an Matan al-Iqnâ' Juz III, h 188.

${ }^{17} \mathrm{Al}$-Bâjî̀, Al-MuntaqâSyarh al-Muwaththa' Juz V, h. 16.

${ }^{18}$ Ibrâhîm ibn 'Alî ibn Yûsuf al-Syîrâzî, Al-Muhadzdzab fî Fiqh al-Imâm al-Syâfi'î Juz I (Bayrût: Dâr al-Fikr, t.t), h. 292.

${ }^{19}$ Makruh dibagi dua makrûh tahrîm dan makrûh tanziî. Makrûh tahrîm adalah sesuatu yang diperintahkan Allah untuk meninggalkannya yang bersifat pasti dan wajib dengan dalil yang bersifat zhannî seperti membeli barang yang sudah dibeli orang lain atau melamar perempuan yang sudah dilamar orang lain. Sedangkan makrûh tanzîh adalah sesuatu yang diperintahkan Allah untuk meninggalkannya yang tidak bersifat pasti dan wajib seperti memakan daging kuda dalam keadaan perang. Lihat Wahbah al-Zuhaylî, al-Wajîz fỉ Ushûl al-Fiqh, (Bayrût: Dâr al-Fikr, 1997), h. 133-134.

${ }^{20}$ Tâj al-Dîn ibn Nashr 'Abd al-Wahhâb ibn Taqiy al-Dîn al-Subkî, Thabaqât al-Syâfi'iyyah alKubrâ Juz VI (Bayrût: Dâr al-Ma'rifah), h. 146, 213, 216. 
jelas yang menunjukkan keharamannya untuk semua orang. ${ }^{21}$

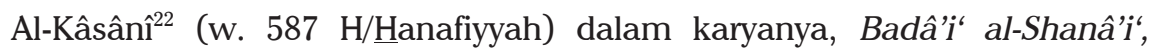
menyatakan bahwa keharaman ihtikâr hanya berlaku untuk dua makanan pokok yaitu kurma dan anggur. Pendapat al-Kâsânî diperkuat oleh Ibn al-Qudâmah ${ }^{23}$ (w. 620 H/Hanâbilah) dalam karyanya, al-Mughnî, yang menyatakan bahwa ihtikâr yang diharamkan adalah ihtikâr makanan pokok, karena semua orang membutuhkannya, sedangkan selain makanan pokok tidak diharamkan, karena tidak semua orang membutuhkannya. ${ }^{24}$

Berbeda dengan al-Kâsânî dan Ibn Qudâmah, Ibn Hazm (w. 456 H) dalam karyanya, al-Muhallâ ${ }^{25}$, menyatakan bahwa ihtikâr terhadap barang-barang yang dibutuhkan masyarakat suatu kesalahan yang dapat merugikan dan menyengsarakan masyarakat banyak. Sedangkan ihtikâr yang tidak dilandasi dengan semangat mencari keuntungan serta masyarakat tidak membutuhkannya maka tidak dikategorikan ihtikâr yang diharamkan oleh syariah.

Pendapat Ibn Hazm diperkuat oleh al-Bâjî (403-494 H) dalam karyanya, alMuntaqâ ${ }^{26}$, yang menyatakan bahwa pelarangan ihtikâr tidak hanya terbatas terhadap makanan pokok, akan tetapi semua barang atau jasa yang benar-benar dibutuhkan oleh masyarakat banyak, karena 'illat pengharamannya adalah alIdhrâr bi al-nâs (dibutuhkan masyarakat), sehingga bersifat umum atau muthlaq, tidak muqayyad, karena berdasarkan kaidah umum penyebutan salah satu barang yang bersifat umum tidak bisa mengkhususkan keumumannya. Pendapat Ibn Hazm (w 456 H) dan al-Bâjî (403-494 H) selaras dengan pendapat Imam Mâlik (93-179 H) dalam karyanya, al-Mudawwanah al-Kubrâ ${ }^{27}$, dan Ibn Taymiyyah (661-728 H) dalam karyanya, al- $\underline{\text { Hisbah, }}{ }^{28}$

\section{Peran Pemerintah terhadap Perilaku Monopoli}

Ketidaksempurnaan ekonomi yang diakibatkan oleh perilaku yang dapat merusak struktur ekonomi berupa rekayasa dari sisi penawaran seperti monopoli (ihtikâr) perlu dicarikan solusi alternatif yang dapat melindungi para pelaku ekonomi seperti pedagang dan pembeli. Islam menawarkan konsep yang

${ }^{21}$ Muhammad al-Husaynî, Miftah al-Karamah fi Syarh Qawa'id al-'Allâmah, (al-Qâhirah: 1326 H), h. 107.

\footnotetext{
${ }^{22}$ Al-Kâsânî, Badâ'i‘ al-Shanâ'i` Juz VI, h. 2972.

${ }^{23}$ Ibn Qudâmah, Al-Mughnî Juz IV, h. 167.

${ }^{24}$ Al-Syarbînî, Mughnî al-Muhtâj Juz II, h. 38 .

${ }^{25}$ Ibn Hazm, Al-Muhallâ Juz IX (Al-Qahirah: Al-Maktabah al-Munîriyyah, 1947), h. 64 .

${ }^{26} \mathrm{Al}$-Bâjî, Al-Muntaqâ Juz $V$, h. 160.

${ }^{27}$ Mâlik ibn Anas, Al-Mudawwanah al-Kubrâ Juz III (Bayrût: Dâr al-Fikr, 1978), h. 290.

${ }^{28}$ Ibn Taymiyah, Al- $\underline{H i s b a h, ~ h . ~} 38$.
} 
antisipatif dan preventif terhadap perilaku-perilaku yang dapat merusak struktur ekonomi, yaitu dengan memaksimalkan peran pemerintah untuk melakukan pengawasan terhadap aktivitas ekonomi, sehingga akses informasi dapat dirasakan dan dinikmati oleh semua pihak yang terlibat dalam aktivitas ekonomi serta menciptakan harga yang adil (tsaman al-mitsl) yang pada akhirnya dapat mewujudkan keseimbangan ekonomi (economic equilibrium). Hal tersebut dapat direalisasikan dengan upaya-upaya sebagai berikut.

\section{Tindakan Preventif}

Pertama, mencegah talaqqî al-rukbân. Yakni tindakan yang dilakukan oleh pedagang yang memiliki informasi lengkap untuk membeli barang produsen yang tidak memiliki informasi benar tentang harga untuk mendapatkan harga yang lebih murah dari yang sesungguhnya. ${ }^{29}$ Para ulama berbeda pendapat mengenai status hukum talaqqî al-rukbân.

Transaksi ini dalam pandangan Abû Hanîfah hukumnya makrûh tahrîm apabila tujuannya untuk merekayasa penawaran, yaitu mencegah masuknya barang ke pasar (entry barrier) atau mencegah penjual dari luar kota untuk mengetahui harga sesungguhnya yang berlaku. ${ }^{30}$ Akan tetapi apabila tujuannya bukan untuk merekayasa penawaran atau mencegah penjual dari luar kota untuk mengetahui harga sesungguhnya, sehingga tidak merugikan pedagang yang datang dari daerah lain juga tidak merugikan masyarakat banyak maka hukumnya boleh menurut ketentuan syariah. ${ }^{31}$

Menurut Abû Hanîfah ada dua kemungkinan efek yang diakibatkan oleh talaqqî al-rukbân. Pertama, efek di mana masyarakat akan membeli barang dengan harga yang sangat tinggi karena tingginya permintaan terhadap barang tersebut sedangkan pelaku talaqqî al-rukbân tidak menjual barangnya kecuali dengan harga di atas harga sesungguhnya. Kedua, efek di mana pelaku talaqqî al-rukbân akan menjual barangnya di bawah harga, karena mereka tidak mengetahui harga sesungguhnya. Talaqqî al-rukbân yang mengakibatkan efek

\footnotetext{
${ }^{29}$ Muhammad ibn Ismâ'il Amîr al-Dîn al-Shan'ânî, Subul al-Salâm Syarh Bulûg al-Marâm min Jam'i Adillat al-Ahkâm Juz III (Bayrût: Dâr al-Jayl, 1980), 21. Lihat juga Al-Ramlî, Nihâyat al-Muhtâj Juz III, h. 449. Lihat juga Abû al-Qâsim 'Abd al-Karîm ibn Muhammad al-Râfi'î, Fath al-'Azîz Syarh al-Wajîz Juz VIII (Bayrût: Dâr al-Fikr, t.t), h. 218-219.

${ }^{30}$ Damân Afandî, Majma' al-Anhar Juz II (Dâr Ihyâ' al-Turâts al-'Arabî, 1319 H), h. 70. Lihat juga 'Alâ' al-Dîn ibn 'Alî ibn Muhammad ibn 'Alî ibn 'Abd al-Rahmân al-Hashkafî, al-Darr al-Muhktâr Juz V (Bayrût: Dâr al-Fikr, 1966), 102. Lihat juga Badr al-Dîn Abû Muhammad Mahmûd ibn Ahmad ibn Mûsâ ibn Ahmad ibn al-Husayn al-'Ainî, 'Umdat al-Qârî Syarh Shahîh al-Bukhârî XI (Bayrût: Dâr al-Fikr, t.t), h. 284.

${ }^{31}$ 'Ubayd Allâh ibn Mas'ûd al-Masyhûr bi Shadr al-Syarî‘ah, Syarh al-Wiqâyah bi Hâmisy Kasyf al-ㅍaqâ'iq Juz II, (Al-Mathba'ah al-Adabiyyah, 1318 H), h. 20.
} 
pertama menurut Abû Hanîfah hukumnya makrûh tahrîm, sedangkan yang mengakibatkan efek yang kedua dalam pandangan Abû Hanîfah diperbolehkan menurut ketentuan syariah. ${ }^{32}$

Berbeda dengan Abû Hanîfah, Imam Mâlik (93-179 H) berpendapat bahwa transaksi ini hukumnya haram, karena orang yang melakukan talaqqî al-rukbân diindikasikan akan menawarkan barangnya dengan harga yang sangat tinggi jauh di bawah harga ketika ia membeli. ${ }^{33}$ Hal ini menurut Mâlik ibn Anas akan merugikan penjual yang tidak mengetahui harga sesungguhnya, juga akan merugikan masyarakat (pihak-pihak yang bertransaksi) karena membeli barang yang ditawarkan dengan harga yang sangat tinggi. ${ }^{34}$

Imam Mâlik mensyaratkan jarak antara pasar dengan tempat terjadinya talqqî al-rukbân yaitu 6 mil, apabila jaraknya kurang dari 6 mil maka menurut Mâlik diperbolehkan. Dalam pandangan Imam Mâlik orang yang melakukan talaqqî al-rukbân yang jaraknya di atas 6 mil menuju pasar diindikasikan akan melakukan permainan harga dengan cara merekayasa penawaran yaitu mencegah masuknya barang atau mencegah penjual dari luar kota untuk mengetahui harga yang berlaku. ${ }^{35}$

Pendapat Imam Mâlik diperkuat oleh Imam Syâfi'i (150-204 H) yang menyatakan bahwa orang yang melakukan transaksi talaqqî al-rukbân apabila tujuannya merekayasa penawaran, yaitu mencegah masuknya barang (entry barrier) atau mencegah penjual dari luar kota untuk mengetahui harga yang berlaku maka hukumnya haram. ${ }^{36}$ Alasan utama pengharamannya menurut Syâfi'i adalah untuk melindungi konsumen yang ada di pasar dari melambungnya harga yang diakibatkan oleh praktik talaqqî al-rukbân dan bukan dalam rangka melindungi penjual, karena penjual mempunyai hak memilih (khiyâr)

\footnotetext{
${ }^{32}$ Akmâl al-Dîn Muhmmmad ibn Mahmûu al-Bâbartî, Syarh al-'Inâyah 'alâ al-Hidâyah bi Hâmisy Fath al-Qadîr Juz VI, (Bayrût: Dâr al-Fikr, 1977), h. 476-477.

${ }^{33}$ Pendapat Mâlik ibn Anas ini merujuk pada Hadis Rasulullah Saw.:

$$
\text { ولا تلقوا السلع حتى يهبط بـا إلى الأسواق(رواه البخاري) }
$$

Dan janganlah kamu mencegat barang-barang sebelum sampai ke pasar (H.r. al-Bukhârî). Lihat Abû 'Abd Allâh Muhammad ibn Ismâ'îl al-Bukhârî, Shahîh $\underline{h}$ al-Bukhârî, (Istambul: Al-Maktabah alIslâmiyyah Muhammad Auzdamîr, 1981), h. 28.

${ }^{34}$ Muhammad ibn Ahmad ibn Muhammad ibn Ahmad ibn Rusyd al-Qurthubî, Bidâyat alMujtahid wa Nihâyat al-Muqtashid Juz II (al-Qahirah: Al-Maktabah al-Tijâriyyah al-Habrî bi Mishrâ, t.t), 144. Lihat juga al-Bâiî, al-Muntaqâ Juz V, h. 101.

${ }^{35}$ Syams al-Dîn Muhammad ibn 'Urfah al-Dasûqî, Hâsyiyat al-Dasûqî 'alâ al-Syarh al-Kabîr Juz III, (Bayrût: Dâr al-Fikr, t.t), h. 70.

${ }^{36}$ Jalâl al-Dîn Muhammad ibn Ahmad al-Muhallâ, Syarh Jalâl al-Dîn al-Muhhallâ 'alâ Minhâj alThâlibîn Juz II, (Bayrût: Dâr al-Fikr, t.t), h. 183.
} 
antara menjual barangnya atau tidak. ${ }^{37}$ Alasan Syâfi'i ini juga dikemukan oleh Imam Mâlik. ${ }^{38}$

Sedikit berbeda dengan ketiga ulama di atas Ahmad ibn Hanbal melarang transaksi ini walaupun tujuannya bukan untuk merekayasa penawaran, yaitu mencegah masuknya barang ke pasar (entry barrier) atau mencegah penjual dari luar kota untuk mengetahui harga yang berlaku. ${ }^{39}$ Dalam pandangan Imam Ahmad ibn Hanbal, alasan pelarangan praktik talaqqî al-rukbân bukan hanya melindungi hak-hak masyarakat yang bertransaksi di pasar, akan tetapi melindungi penjual yang tidak mengetahui harga sesungguhnya, sehingga khiyâr (hak memilih untuk menjual atau tidaknya barang) berdasarkan informasi yang sempurna mengenai harga yang berlaku di pasar ${ }^{40}$ dan mereka tidak merasa ditipu oleh pelaku talaqqî al-rukbân. ${ }^{41}$

Berdasarkan keterangan di atas maka pada dasarnya mayoritas ulama melarang praktik talaqqî al-rukbân karena tidak adilnya tindakan yang dilakukan oleh pedagang kota yang tidak menginformasikan harga yang sesungguhnya. Islam tidak melarang umatnya mencari barang dengan harga yang lebih murah, namun apabila transaksi jual beli antara dua belah pihak di mana yang satu memiliki informasi yang lengkap tentang harga dan yang lainnya tidak, kemudian kondisi ini dimanfaatkan untuk mencari keuntungan yang lebih, maka terjadilah perilaku aniaya yang dilakukan oleh satu pihak (pedagang kota) terhadap pihak lain (penjual/petani di luar kota).

Berdasarkan analisis yang penulis lakukan terhadap perdebatan di atas maka mayoritas ulama merekomendasikan campur tangan pemerintah terhadap pasar untuk membuat regulasi yang dapat meminimalisasi atau bahkan menghilangkan praktik-praktik yang mengarah kepada talaqqî al-rukbân, karena ia akan mengakibatkan praktik monopoli (ihtikâr) yang dapat merugikan masyarakat banyak, sehingga dengan demikian ekonomi senantiasa dalam keseimbangannya, tidak ada yang menzalimi juga tidak ada yang dizalimi.

Kedua, mencegah bay‘ al-hhâdhir li al-bâdî. Yakni praktik makelar (sam-

${ }^{37}$ Al-Mahallî, Syarh Jalâl al-Dîn al-Mahallî 'alâ al-Minhâj Juz II, 183. Lihat juga Syahâb al-Dîn Ahmad al-barlisî al-Mulaqqab bi 'Amîrah, Hâsyiyat 'Amîrah 'alâ Syarh Jalâl al-Dîn Muhammad ibn Ahmad al-Mahallî Juz II (Bayrût: Dâr al-Fikr, t.t), h. 183.

${ }^{38}$ Ibn Rusyd al-Qurthubî, Bidâyat al-Mujtahid wa Nihâyat al-Muqtashid Juz II, 144. Lihat juga alBâjî, al-Muntaqâ Juz V, h. 101.

${ }^{39}$ Al-Buhûtî, Kasysyâf al-Qinâ‘ Juz II, 211. Lihat juga Ibn Qudâmah, Al-Mughnî Juz IV, h. 166.

${ }^{40} \mathrm{Ibn}$ Qudâmah, al-Mughnî Juz IV, h. 165.

${ }^{41}$ Muhammad ibn 'Alî ibn Muhammad al-Syawkânî, Nayl al-Awthâr Juz V, (Al-Qâhirah: Maktabah wa Mathba'ah Mushthafâ al-Bâbî al-Halibî wa Awlâdih, t.t), h. 189. 
sarah) ${ }^{42}$ yang dilakukan oleh seseorang (orang kota) terhadap orang yang datang dari perkampungan (gurun sahara) untuk menjadi perantara dalam menjual barang dengan mengambil keuntungan yang sangat besar dan keuntungan yang diperoleh dari harga yang naik diambil untuk dirinya sendiri. ${ }^{43}$ Transaksi ini berpotensi untuk melambungkan harga yang dapat merugikan masyarakat. ${ }^{44}$

Para ulama berbeda pendapat mengenai hukum dari bay" al-hâdhir li albâdî, al-Marghînânî (w. 593 H), dalam karyanya, Syarh Bidâyat al-Mubtadî bi Hâmis Syarh Fath al-Qadîr, menyatakan bahwa transaksi ini dilarang ketika dalam keadaan paceklik (krisis ekonomi) yaitu ketika masyarakat sangat membutuhkan barang tersebut. Akan tetapi transaksi ini diperbolehkan ketika stabilitas ekonomi dalam keadaan normal. ${ }^{45}$ Karena ketika dalam keadaan

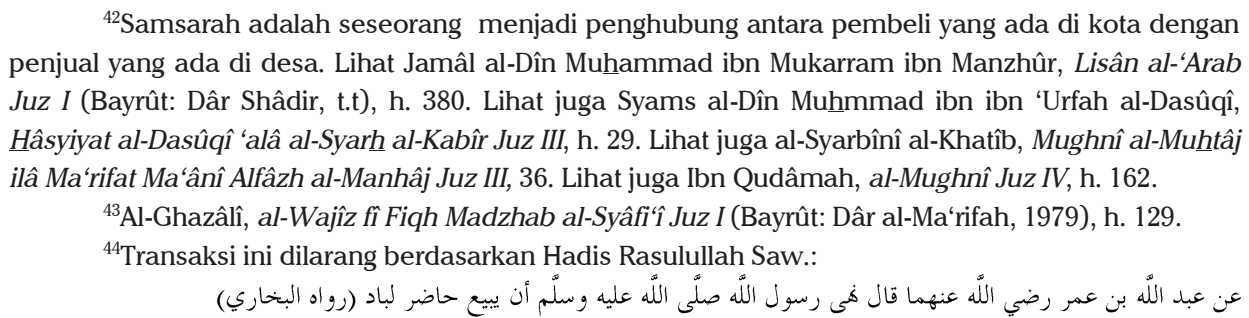

Dari 'Abd Allâh ibn 'Umar semoga Allah meridhai keduanya, Rasulullah Saw. melarang seseorang (orang kota) menjadi perantara orang padang pasir (orang kampung) untuk menjual barangnya (H.r. al-Bukhârî). Lihat al-Bukhârî, Shahîh al-Bukhârî Juz II, h. 27.

Dan Hadis Rasulullah Saw. yang lain:

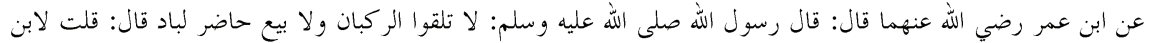

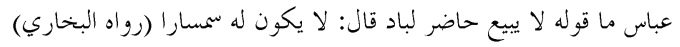

Dari Ibn 'Umar semoga Allah meridhai keduanya berkata, Rasulullah Saw. bersabda, Janganlah kamu sekalian mencegat orang-orang yang membawa barang dari desa dan membeli barang itu sebelum tiba di pasar begitu pula jangan menjadi perantara orang padang pasir (orang kampung) untuk menjual barangnya. Beliau menegaskan terhadap Ibn 'Abbâs yang di maksud dengan bay' hadhir li Bâdin adalah janganlah kamu menjadi makelar (Hadis Riwayat Bukhari). Lihat al-Bukhârî, Shahîh al-Bukhârî Juz II, h. 27.

Dan dipertegas dengan Hadis Rasulullah Saw. yang lain:

$$
\text { عن جابر بن عبد الله رضي الله عنهما أن البي صلى الله عليه وسلم قال: لا يبيع حاضر لباد. دعوا الناس يرزق الله بعضهم من }
$$

Dari Jâbir ibn 'Abd Allah semoga Allah meridhai keduanya bahwasannya Rasulullah Saw. bersabda, "Janganlah menjadi perantara orang padang pasir (orang kampung) untuk menjual barangnya. Biarkanlah mereka bertransaksi sesuai kehendaknya niscaya Allah akan memberi satu sama lain di antara mereka." (H.r. al-Tirmidzî). Lihat Abû "Isâ Muhammad ibn 'Isâ ibn Sûrah al-Tirmidzî, Sunan al-Tirmidzî Juz II, (al-Madînah al-Munawwarah: al-Maktabah alSalafiyyah, 1964), h. 347.

${ }^{45}$ Burhân al-Dîn 'Alî ibn Abî Bakr al-Marghînânî, Syarh Bidâyat al-Mubtadî bi Hâmis Syarh Fath al-Qadîr VI, (Bayrût: Dâr al-Fikr, 1977), h. 478. 
normal tidak akan merugikan pihak-pihak yang bertransaksi secara khusus, dan bagi semua masyarakat secara umum.

Pendapat al-Marghînânî (w 593 H) diperkuat oleh al-Râfi'î (w 623 H) dalam karyanya, Fath al-'Azîz ${ }^{46}$, yang menyatakan bahwa apabila masyarakat sangat membutuhkan terhadap barang yang menjadi objek transaksi (bay' al-hâdhir li al-bâdî), maka tidak seorangpun yang diperbolehkan untuk melakukan transaksi tersebut. Karena apabila transaksi terjadi maka menurut al-Râfi'î ada indikasi orang tersebut (pelaku transaksi bay' al-hâadhir li al-bâdî) akan melakukan manipulasi harga dengan cara melipatgandakan harga jauh di atas harga yang sebenarnya. Hal ini mereka lakukan untuk mencari keuntungan yang sangat besar, karena mereka mengetahui bahwa berapapun harga yang mereka tentutan, masyarakat pasti menerimanya, karena mereka sangat membutuhkannya.

Berbeda dengan al-Marghînânî dan al-Râfi'î, al-Bâjî (403-494H) dalam karyanya, al-Muntaqât ${ }^{47}$, lebih menitikberatkan pada keterlibatan ahl al-bâdî (orang kampung) dalam transaksi. Apabila transaksi ini tidak melibatkan ahl albâdî (orang kampung) maka transaksi ini (transaksi yang melibatkan orang ketiga sebagai penghubung atau makelar) menurut pandangan mereka diperbolehkan. Hal ini disebabkan karena biasanya ahl al-bâdî (orang kampung) tidak mengetahui harga sesungguhnya, sehingga dengan mudahnya seorang makelar akan mempermainkan harga demi mendapatkan keuntungan yang sangat besar. Berbeda halnya dengan orang kota yang senantiasa mengetahui harga yang sebenarnya berlaku, sehingga mereka dapat menjual barangnya sendiri atau menggunakan jasa makelar tanpa harus mengalami penipuan yang dapat merugikannya.

Sedangkan Ibn Qudâmah (w $620 \mathrm{H}$ ) dalam karyanya al-Mughnî ${ }^{48}$ mempunyai argumen yang sedikit berbeda dengan pandangan ulama sebelumnya. Ibn Qudâmah mensyaratkan ahl al-bâdî (orang kampung) tidak mengetahui harga sesungguhnya, sedangkan ahl al-hâadhir (orang kota) mengetahui harga sesungguhnya. Dengan demikian transaksi ini menjadi boleh ketika keduanya sama-sama mengetahui harga sesungguhnya, karena ketika ahl al-bâdî memiliki pengetahuan yang sempurna tentang harga sesungguhnya, maka mereka tidak akan tertipu dengan upaya ahl al-hâadhir untuk mengelabuinya sehingga menjual barangnya dengan harga jauh di bawah harga sesungguhnya.

Para ulama juga berbeda pendapat mengenai status hukum ketika transaksi benar-benar telah berlangsung. Ibn Rusyd (w 595 H) dalam karyanya,

\footnotetext{
${ }^{46} \mathrm{Al}$-Râfi'î, Fath al-'Azîz Juz VIII, h. 217.

${ }^{47} \mathrm{Al}$-Bâîi, al-Muntaqâ Juz V, h. 103.

${ }^{48}$ Ibn Qudâmah, al-Mughnî Juz IV, h. 163.
} 
Muqaddimât ibn Rusyd, menyatakan bahwa status jual belinya tidak batal atau sah, karena menurut Ibn Rusyd status larangan yang terkandung dalam hadis tidak berkaitan dengan akad, akan tetapi lebih kepada upaya perbuatan untuk melakukan transaksi tersebut. ${ }^{49}$

Pendapat Ibn Rusyd memperkuat argumen al-Ghazâlî (450-505 H) dalam karyanya, al-Wajîz fî Fiqh Mazhab al-Imâm al-Syâfi ‘î́ ${ }^{50}$. yang menyatakan bahwa status hukum jual belinya makrûh apabila masyarakat dalam keadaan sangat membutuhkan terhadap barang yang menjadi objek jual beli. Akan tetapi status jual belinya tidak fasâd (rusak), karena makna larangan yang terkandung dalam hadis tersebut tidak mengandung makna fasâd. ${ }^{11}$ Pendapat Ibn Rusyd (w 595 H) dan al-Ghazâlî diperkuat oleh al-Ramlî dalam karyanya, Nihâyat al-Muhtâj ilâ Syarh al-Manhâj ${ }^{52}$, dan al-Maznî dalam karyanya Mukhtashar al-Maznî bi Hamisy al-'Umm, ${ }^{53}$ Berbeda dengan Ibn Rusyd dan al-Ghazâlî, al-Bâjî (403-494 H) dalam karyanya al-Muntaqâ menyatakan bahwa status akadnya fasakh dan fasad, karena larangan terhadap bay` al-hâadhir li al-bâdî menunjukkan kepada fasakh dan fasad-nya akad jual beli tersebut. ${ }^{54}$

Berdasarkan perdebatan di atas, maka campur tangan pemerintah terhadap ekonomi merupakan solusi alternatif untuk meminimalisasi atau bahkan menghilangkan praktik-praktik yang mengarah kepada bay al-hâahir li al-bâd yang mengakibatkan terjadinya monopoli (ihtikâr) dari pihak tertentu. Sehingga dengan demikian perekonomian senantiasa dalam keadilan, tidak ada yang menzalimi juga tidak ada yang dizalimi.

\section{Tindakan Represif}

Islam memberikan wewenang kepada pemerintah untuk melakukan tindakan-tindakan yang menyebabkan efek jera terhadap mereka yang melakukan perbuatan yang dapat merusak tatanan perekonomian masyarakat secara umum. Pemerintah dapat melakukan beberapa alternatif di antaranya dengan cara intervensi harga, memaksanya menjual barang yang ia monopoli, menyita barangnya dan memberi hukuman.

Menurut sebagian ulama, intervensi harga sebenarnya merupakan hal yang

\footnotetext{
${ }^{49}$ Muhammad ibn Muhammad ibn Rusyd, Muqaddimât Ibn Rusyd li Bayân mâ iqtad\}athu alMudawwanah min Ahkkâm Juz III, (Bayrût: Dâr al-Fikr, t.t), h. 203.

${ }^{50}$ Al-Ghazâlî, al-Wajîz Juz I, h. 139.

${ }^{51}$ Al-Bâbartî, Syarh al-'Inâyah 'alâ al-Hidâyah bi Hâmisy Fatḥ al-Qadîr Juz VI, h. 479.

${ }^{52}$ Al-Ramlî, Nihâyat al-Muhtâj Juz III, h. 450.

${ }^{53}$ Ibrâhîm Ismâ‘îl ibn Yahyâ al-Maznî, Mukhtashar al-Maznî bi Hamisy al-'Umm Juz III, (Bayrût: Dâr al-Ma'rifah, 1972), h. 92.

${ }^{54}$ Al-Bâjî, al-Muntaqâ Juz V, h. 104.
} 
tidak popular dalam khazanah pemikiran ekonomi Islam, sebab intervensi harga pada dasarnya dapat menciptakan ketidakadilan. Intervensi harga diperkenankan pada kondisi-kondisi tertentu dengan tetap berpegang teguh pada nilai keadilan. Ketika pelaku ekonomi mengarahkan aktivitas ekonominya kepada cara-cara yang negatif (curang, tipu daya, permainan harga, manipulasi timbangan, dan sebagainya), maka Islam merekomendasikan campur tangan pemerintah melalui sistem hisbah yang berfungsi sebagai pengawas aktivitas ekonomi yang mempunyai otoritas untuk menindak para pelaku ekonomi yang berlaku curang dan membuat intervensi harga.

Mannan dalam karyanya, The Behaviour of Firm and Its Objectives in an Islamic Framework, menyatakan bahwa intervensi harga hendaklah mempunyai landasan yang berbasis kepada peningkatan produktivitas dan peningkatan pendapatan masyarakat miskin melalui alokasi dan relokasi sumber daya ekonomi. Mannan juga menekankan perlunya fungsi sosial dalam memelihara keseimbangan sosial antara masyarakat kaya dan masyarakat miskin. Tidak kalah pentingnya fungsi moral merupakan hal yang sangat urgen demi menegakkan nilai-nilai syariah Islam, khususnya yang berkaitan dengan transaksi ekonomi. $^{55}$

Pada dasarnya, jika aktivitas ekonomi telah bekerja dengan sempurna, maka tidak ada alasan untuk mengatur tingkat harga. Penetapan harga kemungkinan justru akan mendistorsi harga sehingga akhirnya mengganggu aktivitas ekonomi itu sendiri. Pada masa Rasulullah Saw. dan masa khalifah 'Umar ibn al-Khaththâb (w 23 H) kota Madinah pernah mengalami kenaikan tingkat harga barang-barang seperti gandum karena menurunnya pasokan, karena kegagalan panen. Beliau menolak permintaan para sahabat untuk mengatur harga pasar, tetapi kemudian melakukan impor gandum besarbesaran dari Mesir, sehingga penawaran barang-barang di Madinah kembali melimpah dan tingkat harga mengalami penurunan. Namun demikian, pada masa khalifah 'Umar ibn al-Khaththâb (w 23 H) langkah ini ternyata tidak efektif untuk dijadikan alternatif dalam menyelesaikan masalah distorsi yang berlaku di zamannya. Daya beli masyarakat pada waktu itu sangat rendah sehingga Umar mengeluarkan sejenis kupon (yang dapat ditukarkan dengan sejumlah barang tertentu) yang dibagikan kepada fakir miskin. ${ }^{56}$

Oleh karena itu, apabila pemerintah ingin memengaruhi harga, maka yang

${ }^{55}$ Muhammad 'Abd al-Mannân, The Behaviour of Firm and Its Objectives in an Islamic Framework, (Malaysia: Longman, 1992), h. 218-219.

${ }^{56} \mathrm{Al}-$ Hasani Baqir and Mirakhoi Abbas, Essay on Iqtishâd: The Islamic Approach to Economic (1989), h. 78. 
dilakukan adalah dengan cara memengaruhi permintaan dan penawaran, sehingga harga secara otomatis akan menyesuaikan. Penambahan pasokan akan menggeser kurva penawaran ke kanan bawah sehingga tingkat harga turun (cateris paribus), sedangkan peningkatan daya beli masyarakat akan menggeser kurva permintaan ke kanan atas.

Menurut sebagian ulama penetapan harga adalah kebijakan yang tidak dianjurkan oleh ajaran Islam jika pasar dalam situasi normal. ${ }^{57}$ Satu dari empat mazhab terkenal, yaitu Hanbalî, menolak keras kebijakan penetapan harga ini. Mengenai hal ini, Ibn Qudâmah (w. 1239 M/620 H) mengutarakan dua argumentasi. Pertama Rasulullah tidak pernah menetapkan harga walaupun penduduk menginginkannya. Jika penetapan harga ini dibolehkan niscaya Rasulullah akan mengabulkan permintaan masyarakat pada waktu itu. Kedua menetapkan harga menurut Ibn Qudâmah (w. 1239 M/620 H) merupakan ketidakadilan (zhulm) yang dilarang. ${ }^{58}$

Menurut Ibn Qudâmah penetapan harga akan mendorong harga tersebut menjadi lebih mahal. Karena jika para pedagang dari luar mendengar adanya kebijakan penetapan harga ini, maka mereka tidak mau membawa barang dagangannya ke daerah tersebut, di mana ia akan dipaksa menjualnya barang dagangannya di luar yang ia inginkan. Begitu pula pedagang lokal-yang memiliki dagangan—akan menyembunyikan barang dagangannya. Para konsumen yang membutuhkan barang-barang tersebut akan kehilangan kesempatan untuk memenuhi kebutuhannya, karena pasokan barang terbatas. Hal ini akan membuat kedua belah pihak (penjual dan pembeli) menderita. Penjual akan menderita karena penjualan barang mereka dibatasi, sedangkan pembeli menderita karena mereka tidak dapat memenuhi kebutuhannya.

Akan tetapi, yang menjadi pertanyaan selanjutnya adalah, apakah pasar

\footnotetext{
${ }^{57}$ Pendapat ini dikemukakan oleh Abû Muhammad 'Alî ibn Sâîd ibn Hazm dalam karyanya AlMuhallâ Juz IX , Ibn Taymiyah dalam karyanya Majmû' Fatâwâ Ibn Taymiyah , 'Abd al-Rahmân alTharâbalsî dalam karyanya Mawâhib al-Jalîl li Syarh al-Khalîl, Ibrâhîm ibn 'Alî ibn Yûsuf Abû Ishâq alSyîrâzî dalam karyanya al-Muhadzdzab fî Fiqh al-Imâm al-Syâfiî̀, Syams al-Dîn Abû 'Abd Allâh Muhammad ibn Muhammad ibn 'Abd al-Rahnmân al-Tharâbalsî al-Maghribî dalam karyanya Mawâhib al-Jalîl li Syarh Mukhtashar al-Khalîl: Tahqqîq Zakariyâ 'Umayrât Juz V, al-Ghazâlî alam karyanya Ihya' 'Ulûm al-DînJuz II, Syams al-Dîn Muhammad ibn 'Abd Allâh ibn Ahmad ibn Tamratâsy al-Ghazzî dalam karyanya Tanwîr al-Abshâr Juz VI, Muhammad ibn Ahmad ibn Juzî al-Gharnâthî al-Mâlikî dalam karyanya Qawânîn al-Ahkâm al-Syar'iyyah wa Masâ'il al-Furư' al-Fiqhiyyah, Ibn Taymiyyah dalam karyanya al-Hisbah li Ibn Taymiyah, dan Irbrâhîm ibn Mûsâ ibn Muhammad al-Lakhamî al-Gharnâthî al-Syâthibî, dalam karyanya al-Muwâfaqât Juz III.

${ }^{58}$ Pusat Pengkajian dan Pengembangan Ekonomi Islam (P3EI) Universitas Islam Indonesia Yogyakarta kerjasama dengan Bank Indonesia, Ekonomi Islam, (Jakarta: PT RajaGrafindo Persada, 2008), h. 337.
} 
akan selalu dalam keseimbangan atau dalam keadaan normal? Dalam pandangan sebagian ulama, pasar akan mencerminkan keadilan, kerjasama, kesetaraan, dan menjunjung tinggi moralitas ketika ada upaya untuk melakukan pengawasan terhadapnya, baik berupa kontrol sosial maupun kontrol pemerintah, sehingga tercipta keseimbangan ekonomi yang pada akhirnya akan menciptakan keadilan dan kesejahteraan masyarakat secara umum. ${ }^{59}$

Pemerintah dalam Islam mempunyai peran dalam mengatur dan mengawasi ekonomi, memastikan kompetisi berlangsung dengan sempurna, informasi yang merata dan keadilan ekonomi. Penolakan Rasululullah untuk melakukan penetapan harga sebagaimana yang terekam dalam hadisnya tidak lantas menunjukkan bahwa Rasulullah menolak campur tangan pemerintah terhadap aktivitas ekonomi, karena kenaikan harga pada waktu itu terjadi secara alami sesuai dengan kekuatan penawaran dan permintaan. Seandainya kenaikkan harga pada waktu itu tidak terjadi secara alami dan tidak sesuai dengan kekuatan penawaran dan permintaan seperti tindakan monopoli (ihtikâr) yang dapat merugikan masyarakat umum, niscaya Rasulullah akan melakukan intervensi.

Apabila orang yang memonopoli barang enggan menjual barang dan jasanya yang ia monopoli, maka menurut Imam Abû Hanîfah pemerintah harus menyuruhnya untuk menjual barang dan jasa yang dimonopoli, akan tetapi sifatnya tidak memaksa (ijbâr), karena memaksa seseorang untuk menjual barang dan jasanya sudah termasuk kategori hajr (melarang seseorang untuk membelanjakan hartanya) sedangkan ihtikâr menurut Imam Abû Hanîfah tidak termasuk kategori pelanggaran yang dikenakan $\underline{\text { hajr. }} .^{60}$

Berbeda dengan Abû Hanîfah, mazhab Mâlikî dan sebagian pengikut Abû Hanîfah mengharuskan pemerintah untuk memaksa pelaku monopoli menjual barang dan jasanya sesuai dengan harga ketika ia membeli barang dan jasanya tersebut. Mereka menyamakan muhtakir dengan al-Muftî al-Mâjin (mufti yang tidak mempunyai keahlian di bidangnya), al-Makârî al-Muflis (penjahat yang bangkrut), al-Thabîb al-Jâhil (dokter yang bodoh) yang mana pemerintah harus melakukan hajr kepada mereka yaitu mencabut hak untuk menjual barang dan

\footnotetext{
${ }^{59}$ Pendapat ini dikemukakan oleh al-Bâjî dalam karyanya al-Muntaqâ Syarh al-Muwaththa' Juz V, al-Râfi'î dalam karyanya Fath al-'Azîz Syarh al-Wajîz VIII, al-Mâwardî dalam karyanya AlFiqh al-Syâfi'î dan al-Nukat wa al-'Uyûn Juz III, Muhammad ibn Jarîr ibn Yazîd ibn Katsîr ibn Ghâlib al'Âmilî dalam karyanya Jâmi' al-Bayân fî Ta'wîl al-Qur'ân: Tahqîiq Ah̆mad Muhammad Syâkir Juz XVII, al-Nawawî dalam karyanya al-Majmû' Syarh al-Muhadzdzab Juz XIII.

${ }^{60}$ Al-Kâsânî, Badâ'i' al-Shanâ'i' Juz VI, 2974. Lihat juga 'Abd Allah ibn Muhammad ibn Sulaymân, Majma' al-Anhar fî Syarh Mutalaqqâ al-Abhar Juz V, (Dâr al-Turâts al-'Arabî, 1319 H), h. 442.
} 
jasanya kecuali untuk kemaslahatan masyarakat umum. ${ }^{61}$ Pendapat Mâlikiyyah dan sebagian mazhab Hanafî diperkuat oleh mazhab Syâfi 'î́ ${ }^{62}$ dan mazhab $\underline{\text { Hanbalî́}}^{63}$ yang merekomendasikan pemerintah untuk memaksa muhtakir menjual barangnya sesuai dengan harga yang telah ditentukan oleh pemerintah.

Gambar

Ihtikâr Mendistorsi Harga Pasar ${ }^{64}$

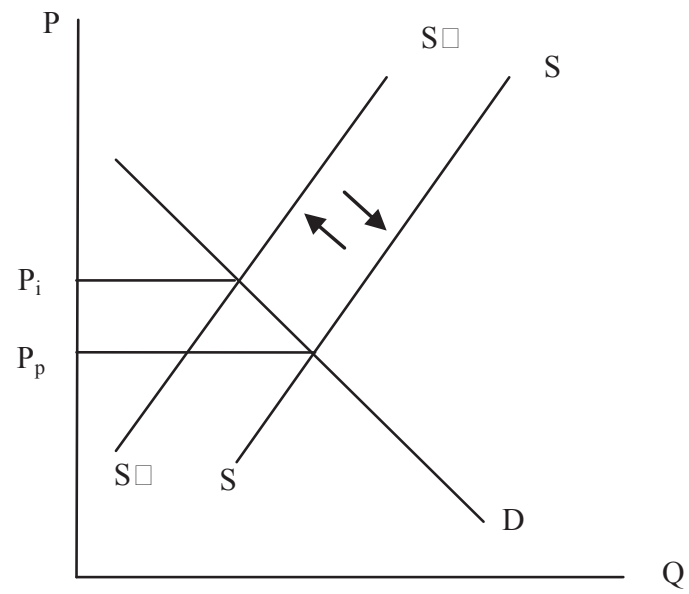

Gambar di atas menunjukkan bagaimana dampak dari tindakan ihtikâr dan pengaruhnya terhadap pembentukan harga. Akibat ihtikâr yang dilakukan penjual, maka kurva penawaran SS bergeser menjadi S'S' dengan tingkat harga berubah dari $\mathrm{P}_{\mathrm{p}}$ menjadi $\mathrm{P}_{\mathrm{i}}$. Pemerintah dapat menetapkan harga dengan mengacu kepada harga pasar. Penetapan harga yang wajar ini akan memaksa penjual untuk menjual kembali barang-barang yang ditimbunnya, sehingga kurva penawaran S'S' kembali menuju SS.

Berdasarkan perdebatan di atas, maka campur tangan pemerintah terhadap pasar ketika terjadi monopoli merupakan solusi alternatif untuk mengem-

${ }^{61}$ Al-Bâjî, Al-Muntaqâ Juz V, h. 17.

${ }^{62}$ Syams al-Dîn Muhammad ibn Abî al-'Abbâs Ahmad ibn Hamrah ibn Shahâb al-Dîn al-Ramlî, Nihâyat al-Muntâj ilâ Syarnh al-Manhâj Juz III, (al-Maktabah al-Islâmiyyah, t.t), h. 456.

${ }^{63}$ Al-Buhûtî, Kasysyâf al-Qinâ' Juz III, 188. Lihat juga 'Alâ' al-Dîn Abû al-Hasan 'Alî ibn Sulaymân al-Mardawî, Al-Anshâf fî Ma'rifat al-Râjih min al-Khilâf Juz IV, (Dâr Ihyâ' al-Turâts al-'Arabî, 1980), h. 339.

${ }^{64}$ Pusat Pengkajian dan Pengembangan Ekonomi Islam Universitas Islam Indonesia Yogyakarta, Ekonomi Islam, h. 334. 
balikan keseimbangan pasar, yaitu dengan cara menentukan harga yang adil (tsaman al-Mitsl) baik untuk penjual maupun pembeli. Apabila dengan kebijakan ini penimbun tidak menjual barang yang ia timbun sedangkan masyarakat sangat membutuhkannya, maka pemerintah mempunyai hak untuk memaksa pelaku penimbunan menjual barang yang ditimbunnya.

\section{Penutup}

Monopoli dalam ekonomi Islam dikenal dengan istilah ihtikâr, yaitu upaya yang dilakukan oleh salah satu pihak dengan cara menimbun barang. Berbeda dengan ekonomi konvensional yang bukan hanya dengan menimbun saja, akan tetapi dengan banyak cara seperti kepemilikan suatu sumber daya yang unik (istimewa) yang tidak dimiliki oleh orang atau perusahaan lain, skala ekonomis dan lain sebagainya. Dengan demikian, apapun yang dilakukan pihak tertentu untuk mencari keuntungan dengan cara membuat kelangkaan suatu barang dikatakan monopoli (ihtikar) dalam perspektif ekonomi Islam. Definisi-definisi monopoli dalam perspektif konvensional yang tujuan dan motifnya menzalimi dan merugikan orang lain, maka dapat dikategorikan monopoli dalam perspektif ekonomi Islam. []

\section{Pustaka Acuan}

'Abd al-Mannân, Muhammad, The Behaviour of Firm and Its Objectives in an Islamic Framework, Malaysia: Longman, 1992.

Abû Dâwud, Sunan Abî Dâwud Juz II, Bayrût: Dâr al-Kitâb al-'Arabî, t.th. Afandî, Damân, Majma' al-Anhar Juz II, Dâr Ihyâ' al-Turâts al-'Arabî, 1319 H.

'Aynî, al-, Badr al-Dîn Abû Muhammad Mahmûd ibn Ahmad ibn Mûsâ ibn Ahmad ibn al-Husayn, 'Umdat al-Qârî Syarh Shahîh al-Bukhârî XI, Bayrût: Dâr alFikr, t.th.

'Alî, ibn Hisam al-Din, Kanz al-'Ummal IV, Jam'iyyat Dâ'irah al-Ma'ârif, 1395 H.

Bâbartî, al-, Akmal al-Dîn Muhammad ibn Mahmûd, Syarh al-'Inâyah 'alâ alHidâyah bi Hâmisy Fath al-Qadîr Juz VI, Bayrût: Dâr al-Fikr, 1977.

Bâjî, al-, al-Muntaqâ Syarh al-Muwaththa’ JuzV, Bayrût: Dâr al-Kitâb al-'arabî, 1332 $\mathrm{H}$.

Baqir, al-, Hasani and Mirakhoi Abbas, Essay on Iqtishâd: The Islamic Approach to Economic, 1989.

Barlisî, al-, Syahâb al-Dîn Ahmad al-Mulaqqab bi 'Amîrah, Hâasyiyat 'Amîrah 'alâ Syarh Jalâl al-Dîn Muhammad ibn Ahmad al-Mahallî Juz II, Bayrût: Dâr alFikr, t.th.

Bayhaqî, al-, Abû Bakr Ahmad ibn al-Husayn ibn 'Alî, Al-Sunan al-Kubrâ Juz VI, 
Haydar Âbâd: Majlis Dâ'irat al-Ma‘ârif al-Nizhâmiyyah al-Kâ'inah fî al-Hind, $1344 \mathrm{H}$.

Buhûtî, al-, Manshûr ibn Yûsuf ibn Idrîs Kasysyâf al-Qinâ' 'an Matan al-Iqnâ', Juz III, Bayrût: 'Âlam al-Kitâb, t.th.

Bukhârî, al-, Abû 'Abd Allâh Muhammad ibn Ismâ‘îl, Shahîh al-Bukhârî, Istambul: al-Maktabah al-Islâmiyyah Muhammad Auzdamîr, 1981.

Case, Karl E. and Ray C. Fair, Principles of Economics, terj Benyamin Molan, Prinsip-Prinsip Ekonomi Mikro, Jakarta: PT Prenhallindo, 2002.

Dasûqî, al-, Syams al-Dîn Muhammad ibn 'Urfah, Hâsyiyat al-Dasûqî 'alâ al-Syarn al-Kabîr Juz III, Bayrût: Dâr al-Fikr, t.th.

Ghazâlî, al-, al-Wajîz fî Fiqh Madzhab al-Syâfi'î Juz I, Bayrût: Dâr al-Ma'rifah, 1979. Hashkafi, al-, 'Alâ' al-Dîn ibn 'Alî ibn Muhammad ibn 'Alî ibn 'Abd al-Rahnmân, alDarr al-Muhktâr Juz V, Bayrût: Dâr al-Fikr, 1966.

Husaynî, al-, Muhammad, Miftâh al-Karâmah fî Syarh Qawa'id al-'Allâmah, alQahirah: $1326 \mathrm{H}$.

Ibn Anas, Mâlik, Al-Mudawwanah al-Kubrâ Juz III, Bayrût: Dâr al-Fikr, 1978.

Ibn Hazm, al-Muhallâ Juz IX, al-Qâhirah: al-Maktabah al-Munîriyyah, 1947.

Ibn Katsîr, Tafsîr Ibn Katsîr Juz III, Mesir: Dâr ihyâ al-Kutub al-'Arabiyyah, t.th. Ibn Mâjah, Sunan Ibn Mâjah Juz II, Bayirut: Dâr al-Fikr, t.th.

Ibn Manzhûr, Jamâl al-Dîn Muhammad ibn Mukarram, Lisân al-'Arab Juz I, Bayrût: Dâr Shâdir, t.th.

Ibn Qudâmah, Abû Muhammad 'Abd Allâh ibn Ahmad ibn Muhammad, alMughnî Juz IV, al-Qâhirah: Maktab al-Qâhirah, 1968.

Ibn Rusyd, Muhammad ibn Ahmad ibn Muhammad ibn Ahmad al-Qurthubî, Bidâyat al-Mujtahid wa Nihâyat al-Muqtashid Juz II, al-Qâhirah: Al-

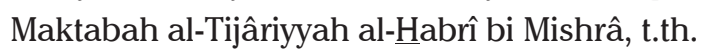

Ibn Rusyd, Muhmmmad ibn Muhmmad, Muqaddimâh Ibn Rusyd li Bayân mâ Iqtadhath al-Mudawwanah min Ahkâm Juz III, Bayrût: Dâr al-Fikr, t.th.

Ibn Sulaymân, 'Abd Allâh ibn Muhammad, Majma' al-Anhar fî Syarh Mutalaqqâ alAbhar Juz V, Dâr al-Turâts al-'Arabî, 1319 H.

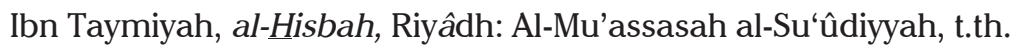

Kâsânî, al-, 'Alâ' al-Dîn Abû Bakr ibn Mas'ûd, Badâ'i' al-Shanâ'i' fî Tartîb al-Syarâ'i' Juz VI, Zakariyyâ 'Alî Yûsuf, t.th.

Mankiw, N. Gregory, Principles of Economics, New York: Harcourt College Publishers, 2001.

Mardawî, al-, 'Alâ' al-Dîn Abû al-Hasan 'Alî ibn Sulaymân, al-Anshâf fî Ma'rifat alRâjih min al-Khilâf Juz IV, Dâr Ihyâ' al-Turâts al-'Arabî, 1980.

Marghînânî, al-, Burhân al-Dîn 'Alî ibn Abî Bakr, Syarh Bidâyah al-Mubtadî bi 
Hâmis Syarh Fath al-Qadîr VI, Bayrût: Dâr al-Fikr, 1977.

Masyhûr, al-, 'Ubayd Allah ibn Mas'ûd, Syarh al-Wiqâyah bi Hâmisy Kasyf alHaqâ'iq Juz II, Al-Mathba'ah al-Adabiyyah, $1318 \mathrm{H}$.

Maznî, al, Ibrâhîm Ismâ‘îl ibn Yahyâ, Mukhtashar al-Maznî bi Hamisy al-'Umm Juz III, Bayrût: Dâr al-Ma'rifah, 1972.

Mahallî, al, Jalâl al-Dîn Muhammad ibn Ahmad, Syarh Jalâl al-Dîn al-Muhallâ 'alâ Minhâj al-Thâlibîn Juz II, Bayrût: Dâr al-Fikr, t.th.

Pusat Pengkajian dan Pengembangan Ekonomi Islam (P3EI) Universitas Islam Indonesia Yogyakarta kerjasama dengan Bank Indonesia, Ekonomi Islam. Jakarta: PT RajaGrafindo Persada, 2008.

Râfi'î, al-, Abû al-Qâsim 'Abd al-Karîm ibn Muhammad, Fath al-'Azîz Syarh alWajîz Juz VIII, Bayrût: Dâr al-Fikr, t.th.

Ramlî, al-, Syams al-Dîn Muhammad ibn Abî al-'Abbâs Ahmad ibn Hamrah ibn Shahâb al-Dîn, Nihâyat al-Muhtâj ilâ Syarh al-Manhâj Juz III, al-Maktabah alIslâmiyyah, t.th.

Shan'ânî, al-, Muhammad ibn Ismâ'il Amîr al-Dîn, Subul al-Salâm Syarh Bulûg alMarâm min Jam'i Adillat al-Ahkâm Juz III, Bayrût: Dâr al-Jayl, 1980.

Subkî, al-, Tâj al-Dîn ibn Nashr 'Abd al-Wahhâb ibn Taqiy al-Dîn, Thabaqât alSyâfi'iyyah al-Kubrâ Juz VI, Bayrût: Dâr al-Ma'rifah, t.th.

Syîrâzî, al-, Majd al-Dîn Muhammad ibn Ya'qûb al-Fayrûz Abâdî, al-Qâmûs alMuhîth Juz II, Bayrût: Dâr al-Fikr, 1398 H.

Syarbînî, al-, Muhammad, Mughnî al-Muhtâj ilâ Ma'rifat Ma'ânî Alfâzh al-Minhâj Juz II, al-Qâhirah: Mushthafâ al-Bâbî al-Halabî wa Awlâdih, 1958.

Syawkânî, al-, Muhammad ibn 'Alî ibn Muhammad, Nayl al-Awthâr Juz V, alQâhirah: Maktabah wa Mathba'at Mushthafâ al-Bâbî al-Halabî wa Awlâdih, t.th.

Syîrâzî, al-, Ibrâhîm ibn 'Alî ibn Yûsuf, al-Muhadzdzab fî Fiqh al-Imâm al-Syâfi'î Juz I, Bayrût: Dâr al-Fikr, t.t.

Tirmidzî, al-, Abû 'Isâ Muhammad ibn 'Isâ ibn Sûrah, Sunan al-Tirmidzî Juz II, alMadînah al-Munawwarah: al-Maktabah al-Salafiyyah, 1964.

Zuhaylî, al-, Wahbah, al-Wajîz fî Ushûl al-Fiqh, Bayrût: Dâr al-Fikr, 1997. 